\title{
Analisa dan Perancangan Sistem Informasi Pendukung Keputusan Berbasis Web untuk Pemilihan Penghuni Asrama UNAI Menggunakan Metode SAW
}

\author{
Yulianus Palopak ${ }^{1}$, Zefanya Lumbantobing ${ }^{2}$ \\ 1,2Fakultas Teknologi Informasi, Universitas Advent Indonesia

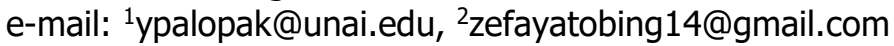

\begin{abstract}
Abstrak
Tujuan dari penelitian ini adalah untuk merancang sebuah sistem berbasis komputer yang dapat digunakan untuk membantu dalam proses pengambilan keputusan. Kebutuhan sistem pendukung keputusan dalam hal penentuan mahasiswa penghuni asrama khusus yang diperuntukkan bagi mahasiswa yang kurang mampu yang berkuliah di Universitas Advent Indonesia (UNAI). Berhubung proses pengambilan keputusan sering melibatkan banyak kriteria maka digunakan sebuah metode yang dapat mendukung dalam pengambilan keputusan yang melibatkan multi kriteria atau Multi Criteria Decision Making (MCDM). Simple Additive Weighting (SAW) merupakan salah satu metode yang umum digunakan dalam mendukung pengambilan keputusan dengan multi kriteria. Model yang ada pada SAW ini digunakan untuk menentukan ranking dari alternatif-alternatif yang ada yang selanjutnya tampilkan dalam bentuk aplikasi komputer berbasis web sehingga memudahkan pengguna baik mahasiswa maupun manajemen UNAI. Hasil dari penelitian ini adalah sebuah sistem pendukung keputusan berbasis komputer berbasis web yang dapat membantu menentukan pengambilan keputusan pada seleksi pendaftaran Asrama Khusus di UNAI. Selanjutnya penelitian ini dapat dikembangkan dengan menggunakan metode yang lain untuk penentuan keputusan yang lebih efektif serta dapat pula ditampilkan dalam platform yang lain seperti aplikasi mobile.
\end{abstract}

Kata Kunci: Sistem Pendukung Keputusan, Metode Simple Additive Weighting (SAW), Multi Criteria Decision Making (MCDM), Sistem Informasi

\section{Analysis and Design of Web-Based Decision Support Systems for the Selection of UNAI's Dormitory Residents Using SAW Method}

\begin{abstract}
The purpose of this study is to design a computer-based system that can be used to assist in the decision making process. The need for a decision support system in terms of determining students for the special dormitory intended for students who are financially incapable who are studying at the Adventist University of Indonesia (UNAI). Usually the decision-making process often involves many criteria, then a method that can support decision making involving multi criteria or Multi Criteria Decision Making (MCDM) is used. Simple Additive Weighting (SAW) is a method that commonly used in supporting multi-criteria decision making. The model in SAW is used to determine the rank of alternatives that are displayed in the form of web-based computer applications so as to facilitate users of both students and UNAI management. The results of this study is a web-based computer-based decision support system that can help to determine decision-making on the selection of Special Dormitory registration at UNAI. Furthermore, this research can be developed using other methods for more effective decision making and can also be displayed on other platforms such as mobile applications.
\end{abstract}

Keywords: Decision Support System, Simple Additive Weighting (SAW) Method, Multi Criteria Decision Making (MCDM), Information System 


\section{Pendahuluan}

Dalam sebuah organisasi, proses pengambilan keputusan merupakan suatu hal yang sangat penting. Pengambilan keputusan dalam sebuah organisasi modern tidak dapat dipisahkan dari kepemimpinan di mana seorang pemimpin harus mampu mengidentifikasi struktur dan proses-proses yang dapat membantu dalam mengambil keputusan terutama dalam berbagai keadaan [1]. Pengambilan keputusan merupakan pemilihan dari beberapa alternatif yang didasarkan pada kriteria terbaik yang sudah ditentukan oleh organisasi yang bersangkutan. Hampir tidak mungkin untuk menggambarkan fitur-fitur penting dari suatu objek menggunakan satu kriteria, sehingga sejumlah atribut [2].

Universitas Advent Indonesia (UNAI) merupakan sebuah lembaga pendidikan yang cukup besar yang menerapkan sistem pemondokan atau asrama bagi sebagian besar mahasiswanya. Dalam menjalankan fungsinya, UNAI menerima mahasiswa dari berbagai kalangan dan status di mana terdapat sebagian mahasiswa yang tidak mampu membayar biaya perkuliahan. Untuk membantu permasalahan tersebut, UNAI menyediakan beberapa jenis asrama dengan fasilitas dan harga yang berbeda. Terdapat asrama khusus yang diperuntukkan bagi mahasiswa yang kurang mampu dalam segi keuangan. Asrama tersebut jauh lebih murah dibandingkan dengan jenis asrama yang lain yaitu asrama standar dan asrama VIP. Setiap semester mahasiswa yang ingin tinggal di asrama khusus, harus mengajukan permohonan ke bagian kemahasiswaan dengan memenuhi beberapa kriteria.

Hal tersebut membutuhkan dukungan sistem informasi untuk dapat memfasilitas mahasiswa dalam mendaftar maupun memberikan kemudahan dan dukungan bagi manajemen UNAI untuk memutuskan mahasiswa yang benar-benar membutuhkan asrama khusus tersebut. Untuk mempermudah dan membantu para pimpinan manajemen dalam mengambil suatu keputusan yang strategis maka dibutuhkan dukungan sistem informasi berbasis komputer [3].

Dengan berkembangnya pemrograman komputer, memungkinkan untuk dapat merangkai dan membentuk algoritma-algoritma yang tersusun sedemikian rupa untuk proses pengambilan keputusan berdasarkan kriteria-kriteria tertentu. Sistem yang dibangun harus dapat memfasilitasi mahasiswa dalam menyampaikan permohonan atau lamaran serta di sisi lain akan memudahkan pengambil keputusan di UNAI untuk menentukan mahasiswa mana yang paling membutuhkan asrama berdasarkan kriteria yang sudah ditentukan.

Salah satu metode yang dapat digunakan dalam mendukung pengambilan keputusan di UNAI dalam menyeleksi para mahasiswa calon pengguna asrama khusus adalah metode Simple Addictive Weighting (SAW) [4],[5] yang akan dituangkan ke dalam sistem informasi berbasis web. Metode Simple Additive Weighting (SAW) merupakan salah satu metode Multi Attribute Decision Making (MADM) yang dapat digunakan untuk mendapatkan alternatif yang optimum untuk berbagai kriteria [6]. MADM merupakan metode proses pengambilan keputusan yang dikenal dengan penggunaan metode dan prosedur berbagai kriteria yang saling bertentangan ke dalam proses perencanaan manajemen [7]. Metode Simple Additive Weighting merupakan metode yang banyak digunakan dalam pengambilan keputusan yang memiliki banyak atribut [8]. Metode SAW lebih banyak digunakan karena proses perhitungannya lebih mudah dipahami, cepat juga simpel [9].

\section{Metode Penelitian}

Studi pendahuluan dilakukan untuk mengetahui dan menganalisa permasalahan yang dihadapi oleh UNAI khususnya dalam hal penentuan penghuni asrama khusus. Pengumpulan data dan persyaratan sistem dilakukan melalui observasi dan wawancara langsung dengan pihak-pihak yang berhubungan langsung dengan permasalahan seperti Wakil Rektor bidang kemahasiswaan, kepala asrama dan juga beberapa orang mahasiswa yang tinggal dalam asrama khusus UNAI. Selanjutnya dilakukan studi literatur tentang SAW, untuk selanjutnya digunakan dalam mengelola dan menentukan kriteria-kriteria yang digunakan dalam menentukan penghuni asrama. Adapun langkah-langkah yang digunakan dalam menggunakan SAW adalah: 1) menentukan kriteria-kriteria yang akan dijadikan acuan dalam pengambilan keputusan, 2) 
menentukan rating kecocokan setiap alternatif pada setiap kriteria, 3) membuat matriks keputusan berdasarkan kriteria, 4) melakukan normalisasi matriks berdasarkan persamaan yang disesuaikan dengan jenis atribut (atribut keuntungan ataupun atribut biaya) sehingga diperoleh matriks ternormalisasi, 5) menghitung matriks ternormalisasi dengan vector bobot untuk memperoleh nilai terbesar yang dipilih sebagai alternatif terbaik

Selanjutnya hasil perhitungan diterapkan dalam baris-baris kode program pada sistem informasi berbasis web untuk memudahkan mahasiswa dalam meng-input data sebagai calon penghuni asrama khusus UNAI serta memudahkan manajemen UNAI untuk memilih dan memutuskan mahasiswa mana yang berhak untuk tinggal di Asrama Khusus. Metode umum yang digunakan selanjutnya dalam merancang dan mengembangkan sistem adalah menggunakan model Waterfall pada metode SDLC (System Development Life Cycle). Model ini terdiri dari tahapan-tahapan antara lain: analisis; desain; implementasi; testing; pemeliharaan. Pada tahapan analisa kebutuhan sistem, dikumpulkan berbagai kebutuhan sistem seperti kebutuhan fungsional dan non-fungsional. Selanjutnya desain dilakukan menggunakan UML Diagram untuk mendesain usecase, diagram aktivitas serta digaram relasi basis data.

\section{Hasil dan Pembahasan}

\section{Penerapan Metode Simple Additive Weighting}

Metode SAW memberikan kesempatan kepada pengambil keputusan untuk memberikan bobot kepada setiap atribut yang akan digunakan. Selanjutnya skor total akan didapatkan dengan menjumlahkan hasil perhitungan dari rating dan bobot masing-masing atribut. Untuk mendapatkan hasil Metode SAW membutuhkan proses normalisasi matriks keputusan $(X)$ ke suatu skala yang dapat diperbandingkan dengan semua rating alternatif yang ada [10], [11].

Adapun langkah-langkah penggunaan SAW dalam mendukung proses pengambilan keputusan diuraikan sebagai berikut (Isnaini Nur Hanifah, 2014)

1. Menentukan kriteria-kriteria yang akan digunakan sebagai acuan dalam pengambilan keputusan, yaitu $\mathrm{C}_{\mathrm{i}}$.

2. Selanjutnya membuat sebuah matriks keputusan $\mathrm{X}$ berukuran $\mathrm{m} \times \mathrm{n}$, di mana $\mathrm{m}=$ alternatif; $\mathrm{n}=$ kriteria .

3. Memberikan nilai pada setiap alternatif (i) untuk setiap kriteria (j) yang sudah ditentukan, di mana $\mathrm{i}=1,2, \ldots \mathrm{m}$ dan $\mathrm{j}=1,2, \ldots \mathrm{n}$ pada matriks keputusan $\mathrm{X}$,

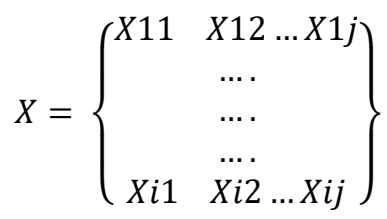

4. Memberikan nilai bobot preferensi $(W)$ oleh pengambil keputusan untuk masing-masing kriteria yang sudah ditentukan. $\mathrm{W}=[\mathrm{W} 1 \mathrm{~W} 2 \mathrm{~W} 3 \ldots \mathrm{Wj}]$

5. Melakukan normalisasi matriks keputusan dengan cara menghitung nilai rating kinerja ternormalisasi (rij) dari alternatif Ai pada atribut $\mathrm{Cj}$.

$$
r_{i j}= \begin{cases}\frac{\mathrm{x}_{i j}}{\max _{i} \mathrm{X}_{i j}} & \text { jika } j \text { atribut keuntungan (benefit) } \\ \frac{\min _{i} \mathrm{x}_{i j}}{\mathrm{x}_{i j}} & \text { jika } j \text { atribut biaya }(\text { cost })\end{cases}
$$

Atribut $\mathrm{j}$ dikatakan atribut keuntungan apabila atribut banyak memberikan keuntungan bagi pengambil keputusan, di mana semakin tinggi nilai kriteria, semakin besar peluang untuk mendapatkan skor 
tertinggi, sedangkan atribut biaya merupakan atribut yang banyak memberikan pengeluaran jika nilainya semakin besar bagi pengambil keputusan, digunakan jika semakin tinggi nilai kriteria, semakin rendah peluang untuk mendapatkan skor tertinggi [12]. Apabila berupa atribut keuntungan maka nilai (xij) dari setiap kolom atribut dibagi dengan nilai (MAX xij) dari tiap kolom, sedangkan untuk atribut biaya, nilai (MIN xij) dari tiap kolom atribut dibagi dengan nilai (xij) setiap kolom [13].

6. Membuat matriks ternormalisasi $(\mathrm{R})$ hasil dari nilai rating kinerja ternormalisasi (rij)

7. Melakukan proses perankingan dengan cara mengalikan matriks ternormalisasi $(R)$ dengan nilai bobot preferensi (W).

8. Menentukan nilai preferensi untuk setiap alternatif (Vi) dengan cara menjumlahkan hasil kali antara matriks ternormalisasi $(R)$ dengan nilai bobot preferensi(W).

Selanjutnya penggunaan SAW dalam mendukung proses pengambilan keputusan di UNAI dapat diuraikan sebagai berikut:

\section{Penentuan Kriteria}

Pada penelitian ini diperlukan kriteria dari tiap-tiap mahasiswa dan mahasiswi yang melamar untuk menghuni asrama khusus. Penerimaan calon penghuni Asrama Khusus di Universitas Advent Indonesia yang layak lolos seleksi harus berdasarkan kriteria yang sudah ditentukan oleh Pembantu Rektor III Bidang Kemahasiswaan. Terdapat tujuh kriteria yang digunakan dalam menentukan mahasiswa sebagai penghuni asrama khusus di UNAI seperti pada tabel 1 berikut.

Tabel 1. Kriteria yang digunakan

\begin{tabular}{|c|l|}
\hline Kode & \multicolumn{1}{|c|}{ Nama Kriteria } \\
\hline C1 & Penghasilan Orang Tua \\
\hline C2 & Jumlah Tanggungan Orang Tua \\
\hline C3 & Jumlah Saudara Kandung \\
\hline C4 & Bersedia Menempuh 17 SKS \\
\hline C5 & Masak Sendiri \\
\hline C6 & Hutang Mahasiswa \\
\hline C7 & Tarif Listrik \\
\hline
\end{tabular}

Dari kriteria di atas, maka dibuat satu tingkat kepentingan kriteria berdasarkan nilai bobot yang telah ditentukan ke dalam tabel.

\section{a. Penghasilan Orang Tua}

Kriteria penghasilan orang tua digunakan sebagai salah satu kriteria dalam menilai kelayakan seorang mahasiswa untuk menghuni asrama khusus UNAI. Kriteria penghasilan orang tua dibagi atas 5 kelompok yang diberi bobot $1-5$. Semakin tinggi bobot dari jenis penghasilan maka semakin kecil peluang untuk mendapat skor tertinggi. Pembobotan pada kriteria penghasilan orang tua dapat dilihat pada tabel 2.

Tabel 2. Bobot Kriteria Penghasilan Orang Tua

\begin{tabular}{|c|c|}
\hline Penghasilan Orang Tua (C1) & Bobot \\
\hline Penghasilan $\leq 2.000 .000$ & 1 \\
\hline $2.000 .000<$ Penghasilan $\leq 3.500 .000$ & 2 \\
\hline $3.500 .000<$ Penghasilan $\leq 5.000 .000$ & 3 \\
\hline $5.000 .000<$ Penghasilan $\leq 10.000 .000$ & 4 \\
\hline Penghasilan $>10.000 .000$ & 5 \\
\hline
\end{tabular}


b. Jumlah Tanggungan Orang Tua

Kriteria jumlah tanggungan orang tua dibagi atas 5 kelompok yang diberi bobot $1-5$. Semakin tinggi bobot dari jumlah tanggungan maka semakin besar peluang untuk mendapat skor tertinggi. Pembobotan pada kriteria jumlah tanggungan orang tua dapat dilihat pada tabel 3.

Tabel 3. Bobot Kriteria Jumlah Tanggungan Orang Tua

\begin{tabular}{|c|c|}
\hline Jumlah Tanggungan Orang Tua (C2) & Bobot \\
\hline 1 & 1 \\
\hline 2 & 2 \\
\hline 3 & 3 \\
\hline 4 & 4 \\
\hline$>5$ & 5 \\
\hline
\end{tabular}

\section{Jumlah Saudara Kandung}

Kriteria jumlah saudara kandung yang dimiliki oleh mahasiswa yang bersangkutan dibagi atas 5 kelompok yang diberi bobot $1-5$. Semakin tinggi bobot dari jumlah tanggungan maka semakin besar peluang untuk mendapat skor tertinggi. Pembobotan pada kriteria jumlah saudara kandung dapat dilihat pada tabel 4.

Tabel 4. Bobot Kriteria Pernyataan Tidak Mampu Secara Financial

\begin{tabular}{|c|c|}
\hline Jumlah Saudara Kandung kuliah UNAI (C3) & Bobot \\
\hline 1 & 1 \\
\hline 2 & 2 \\
\hline 3 & 3 \\
\hline 4 & 4 \\
\hline$>5$ & 5 \\
\hline
\end{tabular}

\section{d. Bersedia Menempuh 17 SKS}

Pada tabel 5 di bawah menunjukkan pilihan mahasiswa pada kriteria untuk bersedia atau tidak menempuh 17 SKS. Hal ini merupakan kebijakan khusus bagi mahasiswa UNAI yang kurang mampu berhubung yang bersangkutan akan diwajibkan untuk bekerja paruh waktu di kampus. Terdapat 2 jenis pilihan yang diberi bobot 1 jika tidak bersedia dan bobot 5 jika bersedia. Semakin tinggi bobot dari jenis pilihan maka semakin besar peluang untuk mendapat skor tertinggi.

Tabel 4 Bobot Kriteria Bersedia Menempuh 17 SKS

\begin{tabular}{|c|c|}
\hline Bersedia Menempuh 17 SKS (C4) & Bobot \\
\hline Tidak & 1 \\
\hline Ya & 5 \\
\hline
\end{tabular}

\section{e. Masak Sendiri}

Tabel 6 menunjukkan tabel pilihan mahasiswa pada kriteria masak sendiri (tidak makan di cafetaria). Mahasiswa dapat memilih untuk makan di cafetaria yang disediakan oleh UNAI bagi mahasiswa yang tinggal di asrama. Mahasiswa juga dapat memilih untuk masak sendiri artinya tidak makan di cafetaria. Jika mahasiswa memilih "Tidak Setuju" maka bobot nilai kriteria adalah 1, apabila mahasiswa yang memilih "Setuju" maka bobotnya adalah 5 . Semakin tinggi bobot dari jenis pilihan maka semakin besar peluang untuk mendapat skor tertinggi. 
Tabel 6 Bobot Masak Sendiri atau Tidak Makan di Cafetaria

\begin{tabular}{|c|c|}
\hline $\begin{array}{c}\text { Masak Sendiri atau Tidak } \\
\text { Makan di Cafetaria (C5) }\end{array}$ & Bobot \\
\hline Tidak Setuju & 1 \\
\hline Setuju & 5 \\
\hline
\end{tabular}

f. Hutang Mahasiswa

Tabel 7 menampilkan penggolongan jumlah hutang mahasiswa. Hutang mahasiswa digolongkan menjadi 5 golongan dengan bobot $1-5$. Semakin tinggi bobot dari jenis pilihan maka semakin besar peluang untuk mendapat skor tertinggi.

Tabel 7. Bobot Kriteria Hutang Mahasiswa

\begin{tabular}{|c|c|}
\hline Hutang Mahasiswa (C6) & Bobot \\
\hline Hutang $\leq 3.000 .000$ & 1 \\
\hline $3.000 .000<$ Hutang $\leq 6.000 .000$ & 2 \\
\hline $6.000 .000<$ Hutang $\leq 9.000 .000$ & 3 \\
\hline $9.000 .000<$ Hutang $\leq 12.000 .000$ & 4 \\
\hline Hutang $>12.000 .000$ & 5 \\
\hline
\end{tabular}

\section{g. Tarif Dasar Listrik}

Kriteria tarif dasar listrik dibagi dalam 5 golongan sesuai dengan besarnya daya listrik yang digunakan di rumah orang tua mahasiswa yang bersangkutan dengan diberi bobot 1-5. Semakin tinggi bobot dari golongan tarif dasar listrik maka semakin kecil peluang untuk mendapat skor tertinggi.

Tabel 8. Bobot Kriteria Tarif Dasar Listrik

\begin{tabular}{|c|c|}
\hline Tarif Dasar Listrik (C7) & Bobot \\
\hline 900 VA -RTM & 1 \\
\hline 1.300 VA & 2 \\
\hline 2.200 VA & 3 \\
\hline 3.500 VA & 4 \\
\hline 6.600 & 5 \\
\hline
\end{tabular}

\section{Perhitungan Nilai Alternatif}

Dari tabel-tabel bobot kriteria di atas, maka dibuat perhitungan tabel untuk rating kecocokan dari tiap alternatif pada setiap kriteria. Sehingga diketahui bobot masing-masing dari kriteria untuk mempermudah proses ke dalam tahap penghitungan berikutnya yaitu dengan membuat suatu tabel untuk mengelompokkan nilai bobot untuk tiap-tiap kriteria. Perhitungan nilai masing-masing alternatif pada penelitian ini menggunakan contoh data dari 5 orang mahasiswa yang melamar pada asrama khusus UNAI. Alternatif-alternatif mahasiswa yang melamar diberi rating kemudian disusun dalam tabel kecocokan. Dalam penentuan rating kecocokan maka nilai dari masing-masing kriteria dimasukkan ke dalam tabel rating kecocokan yang telah disesuaikan dengan nilai dari tabel kriteria. Adapun tabel rating kecocokan dari kriteria-kriteria pelamar asrama khusus UNAI dapat dilihat sebagai berikut:

Tabel 9. Rating kecocokan alternatif per kriteria

\begin{tabular}{|c|c|c|c|c|c|c|c|}
\hline \multirow{2}{*}{ Alternatif } & \multicolumn{7}{|c|}{ Nilai Bobot } \\
\cline { 2 - 9 } & C1 & C2 & C3 & C4 & C5 & C6 & C7 \\
\hline Mahasiswa A1 & 2 & 1 & 1 & 1 & 5 & 3 & 2 \\
\hline Mahasiswa A2 & 4 & 2 & 2 & 1 & 1 & 1 & 1 \\
\hline Mahasiswa A3 & 5 & 3 & 3 & 1 & 5 & 3 & 5 \\
\hline Mahasiswa A4 & 1 & 3 & 2 & 1 & 5 & 3 & 2 \\
\hline Mahasiswa A5 & 1 & 2 & 1 & 1 & 5 & 1 & 1 \\
\hline
\end{tabular}


Dari tabel rating kecocokan di atas kemudian dikonversi ke dalam matriks keputusan seperti yang ditampilkan pada matriks $\mathrm{X}$ berikut ini:

$$
X=\left\{\begin{array}{lllllll}
2 & 1 & 1 & 1 & 5 & 3 & 2 \\
4 & 2 & 2 & 1 & 1 & 1 & 1 \\
5 & 3 & 3 & 1 & 5 & 3 & 5 \\
1 & 3 & 2 & 5 & 5 & 3 & 2 \\
1 & 2 & 1 & 1 & 5 & 1 & 1
\end{array}\right\}
$$

Setelah dilakukan pengkonversian ke dalam matriks keputusan langkah selanjutnya melakukan normalisasi matriks $X$ untuk menghitung nilai masing-masing kriteria berdasarkan kriteria yang diasumsikan sebagai kriteria cost dan benefit. Normalisasi dilakukan dengan cara menghitung nilai rating kinerja ternormalisasi (rij) dari alternatif Ai pada kriteria $\mathrm{Cj}$. Terdapat lima kriteria yang dianggap sebagai kriteria benefit dan dua kriteria dikategorikan sebagai kriteria cost seperti terlihat pada tabel 10.

Tabel 10. Atribut Cost dan Benefit

\begin{tabular}{|c|c|c|}
\hline Kode & Nama Kriteria & Benefit/Cost \\
\hline C1 & Penghasilan Orang Tua & Cost \\
\hline C2 & Jumlah Tanggungan Orang Tua & Benefit \\
\hline C3 & Jumlah Saudara Kandung & Benefit \\
\hline C4 & Bersedia Menempuh 17 SKS & Benefit \\
\hline C5 & Masak Sendiri & Benefit \\
\hline C6 & Hutang Mahasiswa & Benefit \\
\hline C7 & Tarif Listrik & Cost \\
\hline
\end{tabular}

Normalisasi Matrix X menggunakan persamaan sebagai berikut:

a) Untuk penghasilan orang tua dimasukkan ke dalam atribut biaya (cost)

$$
\begin{aligned}
& R 11=\frac{M i n(24511)}{2}=\frac{1}{2}=0,5 \\
& R 21=\frac{M i n(24511)}{4}=\frac{1}{4}=0,25 \\
& R 31=\frac{M i n(24511)}{5}=\frac{1}{5}=0,2 \\
& R 41=\frac{\operatorname{Min}(24511)}{1}=\frac{1}{1}=1 \\
& R 51=\frac{\operatorname{Min}(24511)}{1}=\frac{1}{1}=1
\end{aligned}
$$

b) Untuk jumlah tanggungan orang tua termasuk ke dalam atribut keuntungan (benefit)

$$
\begin{aligned}
& R 12=\frac{1}{\operatorname{Max}(12332)}=\frac{1}{3}=0,33 \\
& R 22=\frac{2}{\operatorname{Max}(12332)}=\frac{2}{3}=0,66 \\
& R 32=\frac{3}{\operatorname{Max}(12332)}=\frac{3}{3}=1 \\
& R 42=\frac{3}{\operatorname{Max}(12332)}=\frac{3}{3}=1 \\
& R 52=\frac{2}{\operatorname{Max}(12332)}=\frac{2}{3}=0,66
\end{aligned}
$$


c) Untuk jumlah saudara kandung termasuk ke dalam atribut keuntungan (benefit)

$$
\begin{aligned}
& R 13=\frac{1}{\operatorname{Max}(12321)}=\frac{1}{3}=0,33 \\
& R 23=\frac{2}{\operatorname{Max}(12321)}=\frac{2}{3}=0,66 \\
& R 33=\frac{3}{\operatorname{Max}(12321)}=\frac{3}{3}=1 \\
& R 43=\frac{2}{\operatorname{Max}(12321)}=\frac{2}{3}=0,66 \\
& R 53=\frac{1}{\operatorname{Max}(12321)}=\frac{1}{3}=0,33
\end{aligned}
$$

d) Untuk kriteria bersedia menempuh 17 SKS termasuk ke dalam atribut keuntungan (benefit)

$$
\begin{aligned}
& R 14=\frac{1}{\operatorname{Max}(11151)}=\frac{1}{5}=0,2 \\
& R 24=\frac{1}{\operatorname{Max}(11151)}=\frac{1}{5}=0,2 \\
& R 34=\frac{1}{\operatorname{Max}(11151)}=\frac{1}{5}=0,2 \\
& R 44=\frac{1}{\operatorname{Max}(11151)}=\frac{5}{5}=1 \\
& R 54=\frac{1}{\operatorname{Max}(11151)}=\frac{1}{5}=0,2
\end{aligned}
$$

e) Untuk kriteria bersedia masak sendiri atau tidak makan di cafetaria termasuk ke dalam atribut keuntungan (benefit)

$$
\begin{aligned}
& R 15=\frac{5}{\operatorname{Max}(51555)}=\frac{5}{5}=1 \\
& R 25=\frac{1}{\operatorname{Max}(51555)}=\frac{1}{5}=0,2 \\
& R 35=\frac{5}{\operatorname{Max}(51555)}=\frac{5}{5}=1 \\
& R 45=\frac{5}{\operatorname{Max}(51555)}=\frac{5}{5}=1 \\
& R 55=\frac{5}{\operatorname{Max}(51555)}=\frac{5}{5}=1
\end{aligned}
$$

f) Untuk kriteria jumlah hutang termasuk ke dalam atribut keuntungan (benefit)

$$
\begin{aligned}
& R 16=\frac{3}{\operatorname{Max}(31331)}=\frac{3}{3}=1 \\
& R 26=\frac{1}{\operatorname{Max}(31331)}=\frac{1}{3}=0,33 \\
& R 36=\frac{3}{\operatorname{Max}(31331)}=\frac{3}{3}=1 \\
& R 46=\frac{3}{\operatorname{Max}(31331)}=\frac{3}{3}=1 \\
& R 56=\frac{1}{\operatorname{Max}(31331)}=\frac{1}{3}=0,33
\end{aligned}
$$

g) Untuk kriteria tarif dasar listrik termasuk ke dalam atribut biaya (cost)

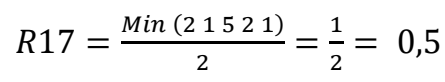

$$
\begin{aligned}
& R 27=\frac{\operatorname{Min}\left(2 \begin{array}{lll}
5 & 5 & 2
\end{array}\right)}{1}=\frac{1}{1}=1 \\
& R 37=\frac{\operatorname{Min}(21521)}{5}=\frac{1}{5}=0,2
\end{aligned}
$$

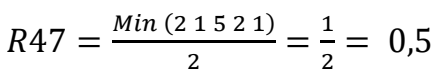

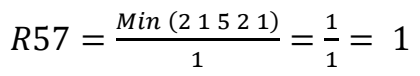


Dari hasil perhitungan di atas maka didapatkan matriks ternormalisasi $(\mathrm{R})$ sebagai berikut:

$$
\text { Matrix } R=\left\{\begin{array}{llllllr}
0,5 & 0,33 & 0,33 & 0,2 & 1 & 1 & 0,5 \\
0,25 & 0,66 & 0,66 & 0,2 & 0,2 & 0,33 & 1 \\
0,2 & 1 & 1 & 0,2 & 1 & 1 & 0,2 \\
1 & 1 & 0,66 & 1 & 1 & 1 & 0,5 \\
1 & 0,66 & 0,33 & 0,2 & 1 & 0,33 & 1
\end{array}\right\}
$$

Matriks ternormalisasi tersebut digunakan untuk melakukan perankingan dengan cara mengalikannya dengan nilai bobot preferensi. Adapun pembobotan ditentukan dengan melihat tingkat kepentingan dari masing-masing kriteria yang sudah ditentukan yaitu: sangat penting (bobot 4), penting (bobot 3), cukup (bobot 2), tidak penting (bobot 1) seperti yang ditunjukkan pada tabel 11. Dari ketujuh kriteria tersebut tidak ada yang dianggap tidak penting.

Tabel 11 Data Bobot Preferensi

\begin{tabular}{|c|c|c|c|}
\hline No & Nama Pembobotan & Nilai/Bobot & Keterangan \\
\hline 1 & Penghasilan Orang Tua & 4 & Sangat Penting \\
\hline 2 & Jumlah Tanggungan Orang Tua & 3 & Penting \\
\hline 3 & Jumlah Saudara Kandung & 2 & Cukup \\
\hline 4 & Bersedia Menempuh 17 SKS & 4 & Sangat Penting \\
\hline 5 & Masak Sendiri & 3 & Penting \\
\hline 6 & Hutang Mahasiswa & 2 & Cukup \\
\hline 7 & Tarif Listrik & 2 & Cukup \\
\hline
\end{tabular}

Nilai bobot preferensi berdasarkan tabel di atas adalah W = [(4), (3), (2), (4), (3), (2), (2)]. Selanjutnya menentukan nilai preferensi untuk setiap alternatif (Vi) dengan cara menjumlahkan hasil kali antara matriks ternormalisasi $(R)$ dengan nilai bobot preferensi(W) dengan menggunakan persamaan berikut..

$$
V i=\sum_{j=1}^{n} w_{j} r_{i j}
$$

Di mana :

$\mathrm{Vi}=$ Nilai akhir dari alternatif

Wj = Bobot yang telah ditentukan

rij = Normalisasi matriks

Nilai Vi yang lebih besar mengindikasikan bahwa alternatif Ai lebih terpilih.

$$
\begin{aligned}
V 1 & =(0,5 \times 4)+(0,33 \times 4)+(0,33 \times 3)+(0,2 \times 2)+(1 \times 3)+(1 \times 2)+(1 \times 2) \\
& =11,45 \\
V 2 & =(0,25 \times 4)+(0,66 \times 4)+(0,66 \times 3)+(0,2 \times 2)+(0,2 \times 3)+(0,33 \times 2)+(1 \times 2) \\
& =8,36 \\
V 3 & =(0,2 \times 4)+(1 \times 4)+(1 \times 3)+(0,2 \times 2)+(1 \times 3)+(1 \times 2)+(0,2 \times 2) \\
& =12 \\
V 4 & =(1 \times 4)+(1 \times 4)+(0,66 \times 3)+(1 \times 2)+(1 \times 3)+(1 \times 2)+(0,5 \times 2) \\
& =18,32 \\
V 5 & =(1 \times 4)+(0,66 \times 4)+(0,33 \times 3)+(0,2 \times 2)+(1 \times 3)+(0,33 \times 2)+(1 \times 2) \\
& =13,1
\end{aligned}
$$

Hasil Perankingan Diperoleh V1 $=11,45, \mathrm{~V} 2=8,36$, V3 $=12, \mathrm{~V} 4=18,32$, V5 $=13,1$. Diperoleh nilai terbesar ada pada V4, sehingga dengan demikian alternatif Mahasiswa A4 adalah alternatif yang terpilih sebagai alternatif terbaik. 


\section{Perancangan Sistem Informasi}

Permasalahan yang sering terjadi di pendaftaran asrama khusus seperti data-data yang disimpan masih berjalan manual, padahal pemeriksaan akan data-data mahasiswa dan mahasiswi yang ingin melamar ke asrama khusus tiap semesternya meningkat. Proses pendaftaran yang dijalankan belum sepenuhnya membantu pekerjaan Pembantu Rektor III Bidang Kemahasiswaan dalam menentukan pengambilan keputusan, karena kebutuhan akan data yang efektif dan efisien serta ada saat dibutuhkan belum bisa terpenuhi menjadi alasan utama untuk penyediaan informasi yang akurat. Penyediaan data yang banyak menyebabkan jumlah yang melebihi batas (overload) pada data dan informasi kurang. Data yang kurang lengkap menyebabkan informasi seleksi pendaftaran di asrama khusus juga kurang, oleh karena data yang tidak tersusun dengan rapi dan susahnya pencarian data mengurangi kurangnya informasi dari data tersebut.

Kesulitan pengambilan keputusan, terutama dalam mempertimbangkan berbagai kriteria masih sering menjadi kendala. Pertimbangan yang objektif sering sulit dilakukan berhubung adanya intervensi baik dari keluarga mahasiswa, maupun dari pihak lain yang menginginkan supaya pelamar tertentu dapat dipilih dan dapat menghuni asrama khusus. Sistem informasi pendukung keputusan yang dikembangkan dengan menggunakan metode SAW diharapkan dapat membantu objektivitas pengambil keputusan dalam menentukan calon penghuni asrama khusus yang tepat.

Dalam sistem yang dibuat, terdapat beberapa fungsi seperti yang terlihat pada gambar 1 antara lain: 1) fungsi login yang digunakan oleh pengguna sistem untuk dapat mengakses dan menggunakan fitur-fitur yang ada, 2) fungsi Pendaftaran, digunakan oleh mahasiswa yang ingin melamar untuk tinggal di asrama khusus UNAI, 3) fungsi Lihat Data, digunakan untuk melihat data mahasiswa yang melamar, 4) fungsi Lihat Seleksi Mahasiswa, digunakan untuk melihat hasil penyeleksian semua pelamar, dan 5) fungsi Data Pengguna, untuk melihat data pengguna sistem.

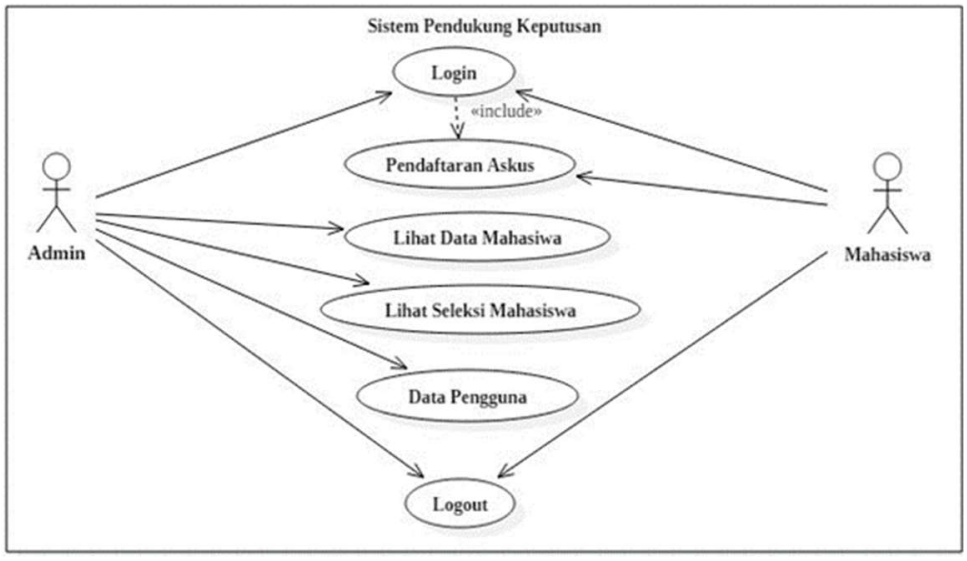

Gambar 1 Use Case Diagram Sistem

\section{Hasil Perancangan}

Setelah user melakukan login, maka userakan dihadapkan pada halaman pendaftaran yang digunakan oleh user mahasiswa yang akan mendaftar asrama khusus. User akan mengisi data pribadi dan mengisi kriteria sesuai tampilan yang telah di sajikan. Sebagaimana pada pembahasan sebelumnya, terdapat tujuh kriteria yang dapat diisi oleh mahasiswa yang melamar. Dari data pengisian kriteria itulah yang akan disimpan ke basis data, lalu akan diambil sebagai nilai dari matriks keputusan dan selanjutnya akan dihitung dengan menggunakan metode SAW. Selain meng-input data pribadi, terdapat juga tombol chose file yang berfungsi untuk upload file seperti surat keterangan tidak mampu, rekening listrik dan surat persetujuan orang tua, yang dapat di-upload dalam bentuk image. 


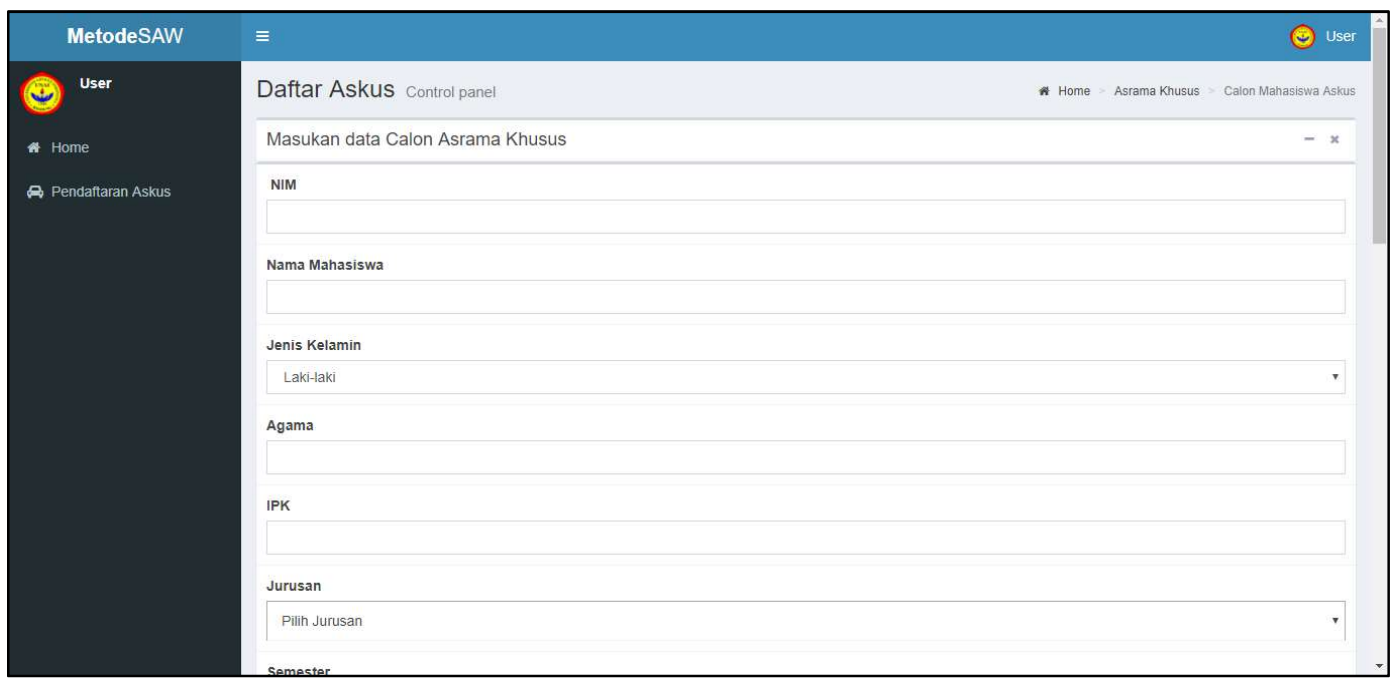

Gambar 2 Halaman Pendaftaran Asrama Khusus

Data yang sudah di-input oleh masing-masing user akan disimpan pada basis data, lalu dapat pula ditampilkan pada form. Pada gambar 3 menunjukkan halaman data klasifikasi yang dimaksudkan untuk mencek kembali data yang telah dimasukkan sehingga data tersebut dapat dilihat kembali oleh pengguna untuk dapat memastikan datanya.

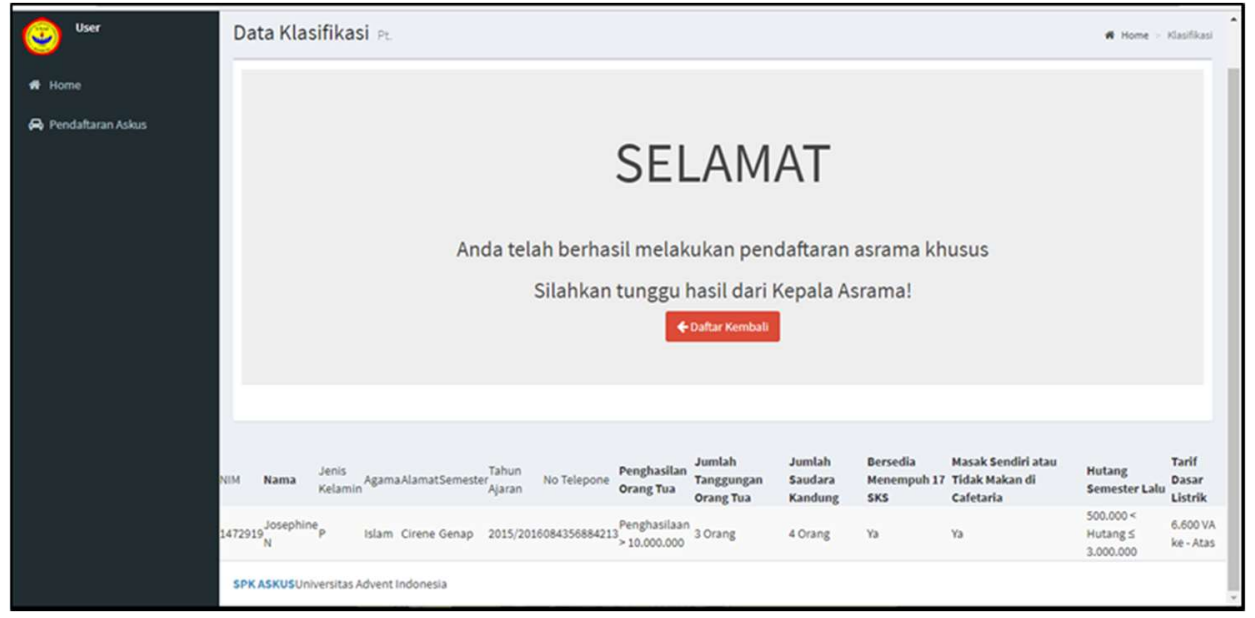

Gambar 3 Halaman Data Klasifikasi

Seluruh data alternatif mahasiswa yang melamar akan disimpan ke dalam sistem sehingga nantinya akan dihitung berdasarkan input kriteria yang sudah dimasukkan oleh masing-masing mahasiswa. Pada Gambar 4 menunjukkan halaman hasil perhitungan SAW yang sudah diproses oleh admin. Pada halaman perhitungan SAW ditampilkan hasil perhitungan dari kriteria dan masukan data bobot yang telah dimasukkan oleh pendaftar. Halaman ini menampilkan perankingan dari alternatif mahasiswa yang ditampilkan berdasarkan urutan besarnya nilai hasil perankingan. Adapun perankingan ini berasal dari alternatif mahasiswa yang dinormalisasi dan kemudian dihitung menjadi perankingan. Dengan demikian bahwa sistem dapat mengurutkan mahasiswa pelamar asrama khusus mulai dari nilai tertinggi yang artinya sebagai alternatif terbaik untuk menjadi penghuni asrama khusus UNAI. 


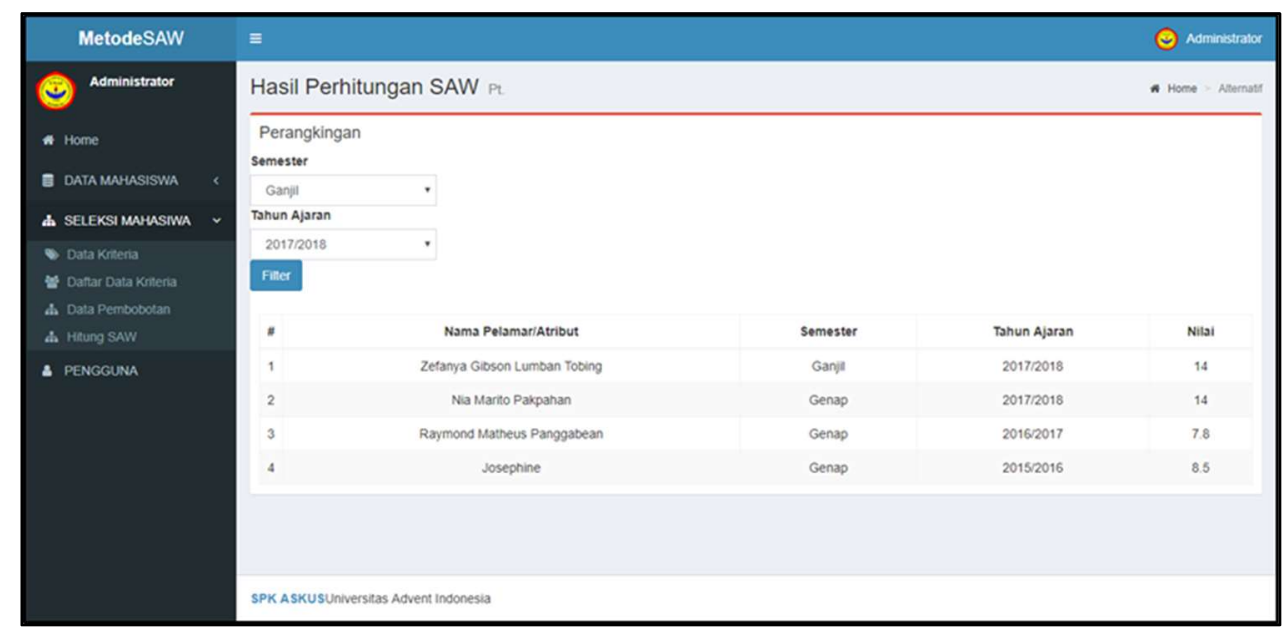

Gambar 4 Halaman Hasil Perankingan

\section{Kesimpulan}

Dari hasil implementasi metode SAW dalam perancangan sistem informasi pendukung keputusan yang dibuat dapat disimpulkan bahwa sistem informasi pendukung keputusan untuk seleksi pendaftaran asrama khusus di Universitas Advent Indonesia menggunakan metode SAW (Simple Additive Weighting) dapat mendukung pengambilan keputusan berdasarkan nilai bobot kriteria yang dihitung pada pengoperasian sistem sehingga dapat menentukan mahasiswa yang berhak tinggal di asrama khusus berdasarkan nilai bobot kriterianya. Sistem juga dapat membuat laporan keputusan yaitu laporan yang menghitung peringkat mahasiswa berdasarkan nilai tertinggi yang dihitung menggunakan metode SAW.

\section{Referensi}

[1] Larry W. Boone \& Ralph H. Kilmann. The Context of Decision Making in Organizations: A Factor Analysis. Advances in Information Processing in Organizations, Volume 4, pp. 147-160, 1991, ISBN:1-55939-012-8.

[2] L. Ustinovichius1 , E.K. Zavadskas1 and V. Podvezko2Application of a quantitative multiple criteria decision making (MCDM-1) approach to the analysis of investments in construction. Control and Cybernetics vol. 36 (2007) No. 1.

[3] Arh, T., \& Blaži, B. J. (2007). Application of Multi-Attribute Decision Making Approach to Learning Management Systems Evaluation . JOURNAL OF COMPUTERS, 2(10), 28-37.

[4] Risawandi and R. Rahim, "Study of the SimpleMulti-Attribute Rating Technique For Decision Support," International Journal of Scientific Research in Science and Technology (IJSRST) , vol. 2, no. 6, pp. 491-494, 2016.

[5] Nurmalini and R. Rahim. Study Approach of Simple Additive Weighting For Decision Support System. 2017 IJSRST | Volume 3 | Issue 3 | Print ISSN: 2395-6011 | Online ISSN: 2395-602X. [(2)3: 541544]

[6] Widayanti-Deni, Oka-Sudana, and Arya-Sasmita. Analysis and Implementation Fuzzy Multi-Attribute Decision Making SAW Method for Selection of High Achieving Students in Faculty Level. International Journal of Computer Science Issues, Vol. 10, Issue 1, No 2, January 2013. ISSN (Print): 1694-0784 | ISSN (Online): 1694-0814. 
[7] Lazim Abdullah and C.W. Rabiatul Adawiyah. Simple Additive Weighting Methods of Multi criteria Decision Making and Applications: A Decade Review. International Journal of Information Processing and Management(IJIPM) Volume 5, Number 1, February 2014.

[8] Fifin Sonata. Implementasi Metode Simple Additive Weighting (Saw) Dengan Proses Fuzzifikasi Dalam Penilaian Kinerja Dosen. Jurnal Teknologi Informasi dan Komunikasi Vol. 5 No.2, Desember 2016 : $71-80$..

[9] Diqy Fakhrun Shiddieq, Ervan Septyan. Analisis Perbandingan Metode Ahp Dan Sawdalam Penilaian Kinerja Karyawan (Studi Kasus Di Pt. Grafindo Media Pratama Bandung) Jurnal LPKIA, Vol.10 No.2, Desember 2017.

[10] Diana Laily Fithri, Noor Latifah. Sistem Pendukung Keputusan Untuk Pemberian Bantuan Usaha Mikro Dengan Metode Simple Additive Weighting. Majalah Ilmiah INFORMATIKA Vol. 3 No. 2, Mei 2012.

[11] Ian Septiana, Mohammad Irfan, Aldy Rialdy Atmadja, Beki Subaeki. Sistem Pendukung Keputusan Penentu Dosen Penguji Dan Pembimbing Tugas Akhir Menggunakan Fuzzy Multiple Attribute Decision Making Dengan Simple Additive Weighting (Studi Kasus: Jurusan Teknik Informatika UIN SGD Bandung). JOIN | Volume I No. 1 | Juni 2016 ISSN 2527-9165.

[12] Muhammad Donni Lesmana Siahaan, Elviwani, Asprina Br. Surbakti, Andre Hasudungan Lubis, Andysah Putera Utama Siahaan. Implementation of Simple Additive Weighting Algorithm in Particular Instance. 2017 IJSRST | Volume 3 | Issue 6 | Print ISSN: 2395-6011 | Online ISSN: 2395$602 X$.

[13] Isnaini Nur Hanifah. Sistem Pendukung Keputusan Pemilihan Guru Berprestasi dengan Simple Additive Weighting. Jurnal Teknik Elektro, Vol. 6 No. 1, 2014. P-ISSN: 1411-0059, E-ISSN: 25491571. 